\title{
Auditor Involvement With Law Enforcement Agencies: A Specialized Niche
}

Arthur F. Hintz, (E-mail: hintz@sjfc.edu), St. John Fisher College

Michael W. Fedoryshyn, (E-mail: fedorysh@sjfc.edu), St. John Fisher College

\begin{abstract}
With over 18,000 state and local law enforcement agencies in the United States, opportunities exist for auditors to assist police agencies design and implement effective and efficient procedures for control of cash and other properties. Auditor involvement can improve police performance and help maintain public confidence in the police department's ability to serve and protect the public interest.
\end{abstract}

The article discusses how auditors can provide a valuable service to police agencies by improving the agencies' internal control over assets entrusted to them as evidence in criminal cases or to aid in their fight against crime. It discusses the needed audit procedures for such an engagement.

The article also discusses the special audit procedures for police agencies, which are involved in the Federal Asset Forfeiture Program.

\section{Introduction}

$\mathscr{R}$

ecent cases involving some of the nation's largest police departments indicate the extent to which easy access to drugs, guns and money can create a powerful temptation for police personnel to engage in illegal activities. Independent auditors, by nature of their objectivity and expertise in evaluating and designing controls, can play an important role in helping law enforcement agencies create an environment that values integrity over opportunity and greed. With over 12,000 local police agencies and 3,000 sheriff departments in the U.S., ample opportunities exist for auditors to become involved in the war on crime.

Twenty years ago, police corruption typically consisted of bribes and payoffs to ignore criminal activity such as bookmaking and prostitution, and was primarily a problem with individual officers. Today, as the amount of money involved in illegal drug operations has escalated, police corruption has changed. The 1994 report of the Mollen Commission, which investigated police corruption in New York City, found that virtually all police corruption involved groups of officers participating in shaking down drug dealers, skimming money from cash seized in drug busts, or stealing money and drugs from suspects.

In Minneapolis, a long time narcotics cop was sentenced to $2 \frac{1 / 2}{2}$ years in prison after admitting to stealing $\$ 335,000$ from the police property room. He would sign money seized from drug dealers out of the police property room and then use the money for his personal gambling purposes. Lack of adequate control procedures for signing evidence into and out of the property room allowed the scheme to go undetected until an alert civilian clerk noticed that money being signed out of the property room was never returned. A subsequent audit indicated that there were no procedures for keeping track of the estimated $\$ 1$ million dollars of cash that had accumulated in vaults below the

Readers with comments or questions are encouraged to contact the authors via email. 
City Hall. The audit raised troubling questions about the potential for further theft and the ability for prosecutors to gain convictions due to misplaced evidence. The audit blamed obsolete procedures that were implemented in the early 1980's before the volume of evidence increased with the dramatic increase in drug cases.

In Rochester, NY, the police chief was convicted of taking $\$ 150,000$ in police department funds and using it for his personal benefit. A primary source of the funds was cash held in a safe in the chief's office intended for use by police officers for undercover drug purchases, paying police informants, and other vice squad activities. Fearing that the ledgers kept to account for the funds might pose a problem, the chief reported that his car had been broken into and the ledgers stolen. Shortly thereafter, he implemented "new" accounting procedures for the funds and gave the officer responsible for the funds a new set of ledgers. Before sentencing the chief to four years in prison and ordering him to pay $\$ 150,000$ to the city in restitution, the judge admonished him for "abusing the public trust and treating the money entrusted to him as his own piggy bank" and said he "owed his former officers, as well as the city, an apology." Immediately after sentencing, at the media crush outside the Federal courthouse, the chief remarked, "I do not feel I stole from the city.... I only regret that I was not a better accountant."

And in Hartford, Conn. and Memphis, Tenn., police officials have come under fire for inappropriately spending money seized in drug investigations. While not claiming that any money was stolen, over $\$ 300,000$ was spent on items not allowed under the Federal Asset Forfeiture Laws, including lawn care services, golf fees, cars for the Mayor and other officials and travel.

\section{Auditor Involvement in Independent Oversight}

A major portion of police corruption results from inadequate checks and balances over their activities. To ensure the system for monitoring police activities operates as designed, the Mollen Commission recommended that New York City create a permanent external police commission to provide independent oversight over the department and audit the department's systems for investigating corruption and conducting investigations. As noted by the Commission, "an effective program of reform must both heighten the department's ability and will to combat corruption internally and must create an external independent mechanism to insure that such ability does not meet a quick demise".

By nature of their skills and experience, independent auditors have a unique opportunity to participate in the process of designing and auditing police departments' systems of internal controls. Two areas of police responsibility that can benefit from involvement by independent auditors include cash received under the Federal Asset Forfeiture Programs, and control of property in police custody. Since cash and inventory are inherently risky assets from a control perspective, adequate procedures need to be in place to safeguard these items. Periodic audits of cash and property maintained by police departments should and are required to be performed.

\section{Overview of the Federal Asset Forfeiture Programs}

In 1984, Congress passed the Comprehensive Crime Control Act to aggressively wage a war on crime. The Act authorized the U.S. Department of Justice to develop a program for seizing assets used or acquired in criminal activities and share proceeds from the sale of forfeited assets with federal, state and local law enforcement agencies.

The Federal Asset Forfeiture Programs were started in 1986 with three major goals:

- To punish and deter criminal activity by depriving criminals of the profits and proceeds of their illegal activities.

- $\quad$ To enhance cooperation among foreign, federal, state and local law enforcement agencies through the equitable sharing of assets recovered through this program.

- $\quad$ To produce revenues to enhance and strengthen law enforcement efforts. 
Any state or local law enforcement agency that participates with a federal law enforcement agency in a criminal investigation resulting in a forfeiture of assets with a minimum dollar threshold is eligible to receive a share of the net proceeds. Net proceeds consists of the gross receipts from the asset less any related expenses to store, appraise or sell the asset and proceeds are shared based on the particular agency's' degree of participation in the investigation.

As of 1994, almost \$1.4 Billion in forfeited assets has been shared with over 3000 law enforcement agencies. The Department of Justice's goals of increased cooperation between law enforcement agencies and additional funds to strengthen law enforcement efforts have been achieved as a result of the Federal Asset Forfeiture Programs.

\section{Audit Requirements for Agencies Participating in the Federal Asset Forfeiture Programs}

With large dollar amounts involved in the forfeiture programs and relatively little federal oversight of state local law enforcement agencies participating in the program, temptations exist for agencies to use the funds in ways not intended by the program. To ensure continued public support and confidence in the Federal Asset Forfeiture Programs, law enforcement agencies that participate in the sharing of forfeiture proceeds are subject to various reporting and audit requirements. Any law enforcement agency that receives over $\$ 100,000$ in assets from the program during the year or had assets of over $\$ 100,000$ on hand at any time during the year must have an independent financial audit of the funds. The audit must be performed by an independent Certified Public Accountant or independent government auditor in conformance with Government Auditing Standards. Even if the agency is not subject to an independent audit it must send an Annual Certification Report to the Department of Justice verifying they are in compliance that agency's standards.

\section{Department of Justice Compliance Requirements}

Major compliance requirements that need to be audited and reported to the Department of Justice include:

- $\quad$ Proceeds from forfeitures, and interest on forfeited funds, must be deposited and accounted for in a separate fund used only for proceeds from the program.

- $\quad$ Funds must be used to supplement the resources of the law enforcement agency and cannot be used for normal operating expenses of the department or the government unit (i.e. funds seized in a drug raid cannot be used to support additional spending for the highway department). Since one of the goals of the program is to strengthen and increase law enforcement efforts, the Department of Justice wants to ensure that funds received under this program do not support activities other than increased law enforcement activities.

- $\quad$ Adequate procedures and internal controls must be in place to account for the proceeds of forfeited assets.

Noncompliance with the requirements of the program may result in recipient agencies being banned from further participation in the program, civil actions for breech of contract, or possible federal criminal actions if fraud or theft is involved. A Federal grand jury in June of 1996 charged the police director in Newark, New Jersey of stealing $\$ 30,000$ from the department's investigation fund used for undercover activities. The director is accused of using the fund as his personal bank account for items such as trips, campaign contributions and gifts for his wife and girlfriend. Additional information on the Federal Asset Forfeiture Programs can be obtained from the Department of Justice or by contacting a local law enforcement agency participating in the program.

\section{Police Department Property Rooms}

With the number of arrests over a ten-year period for drug abuse violations up 56\%, weapons charges up $46 \%$, and property crimes up $13 \%$, control of police department property rooms becomes critical in maintaining the effectiveness of our judicial system. Lack of adequate controls and procedures relating to physical property in police department possession can lead to mistrials and acquittals in criminal trials, or temptations for stealing within the police department. Independent auditors can provide valuable services to ensure that police departments control physical property effectively and efficiently. Police departments that participate in Federal or State Law Enforcement Ac- 
creditation Programs are generally required to perform annual audits of inventory in their property room. While these audits may be assigned to police department personnel, independent auditors have specific expertise in conducting physical inventories and evaluating the effectiveness of controls and procedures in place to safeguard assets. Recommendations for improvements in the controls and procedures of police department property rooms provide opportunities for auditors to contribute to more effective operation of local law enforcement agencies.

\section{Physical Property in Police Custody}

Property in police custody typically found in a police department property room includes:

- $\quad$ Controlled substances, firearms and money confiscated by the police and held as evidence.

- $\quad$ Stolen property recovered by the police awaiting disposition of the case and eventual return to the legitimate owner.

- $\quad$ Found property turned in by a citizen or collected by the police that will eventually be returned to the legal owner given to the finder, or sold at auction.

- Motor vehicles impounded by the police for a variety of reasons, such as unregistered or uninsured vehicles, DWI cases and abandonments.

Police departments need to maintain adequate controls to ensure that the physical property is recorded, stored, and available for its intended purpose. Unlike a business, which intends to resell the property, property held by the police must be available for use as evidence in trial or for return to the rightful owner. An added complication arises since property can leave the custody of a property room numerous times for reasons such as lab testing, evaluation by prosecutors and courtroom evidence.

Maintaining a proper record of the chain of custody of the asset is extremely important when the property is used as evidence in a legal proceeding. During the 1995 O.J. Simpson trial, the defense argued that there was ample opportunity for persons to have obtained access to Simpson's Ford Bronco and driving glove to plant the traces of blood that were central pieces of evidence in the prosecution's case.

Property held by police departments can ultimately be sold at auction, destroyed, returned to the owner or finder, or used for some other authorized purpose such as K-9 training. These factors provide complexities not normally encountered in an audit of a normal manufacturing business.

An additional concern to many police departments and the general public is whether all the firearms, narcotics, and money seized by the police is eventually turned in to the property room. This requires audit procedures outside the scope of those found in a normal audit of inventory. Procedures such as drug testing, hidden cameras, and lifestyle audits might assess whether individuals with access to police property are living a lifestyle inconsistent with their salary, however such tests may violate police union rules.

\section{General Orders}

Police departments are subject to numerous laws and regulations regarding the recording, storage, classification, retrieval, and disposition of physical evidence and recovered property in their possession. Applicable Federal and State laws, Accreditation Standards, and department regulations are summarized in an internal police department document referred to as the General Orders. General Orders provide specific guidance and procedures to police department personnel in areas such as access to the property room, disposal requirements for physical property, required documentation for the movement of physical property, and periodic audit requirements.

Federal and State governments provide opportunities for local police agencies to have their organization accredited. While accreditation at the Federal and State level is not required, many police organizations have chosen to become accredited in the belief that it provides additional defense against lawsuits that may be filed against the department. However, even if police departments choose not to be accredited, the policies and procedures related to 
control of physical property prescribed by accreditation agencies should be met in order for the department to fulfill its statutory and fiduciary obligations.

\section{Property Room Procedures}

Many items enter police custody as a result of a criminal investigation, consequently a written crime report would be associated with the physical property. However, items found and turned in by citizens will not have written crime reports unless the item is a firearm or controlled substance.

The main control document used within a police property room is the Property Custody Report (PCR). Property coming into police custody is listed on a Property Custody Report and includes the crime report number, the defendant's name, the owner's name, and the name of the officer or citizen responsible for bringing the items into custody. This report also records each time the items are transferred out of the property room. Formal documentation of all movement in and out of the property room preserves a record of the chain of custody and is extremely important for property used as evidence in a criminal trial.

Accreditation standards generally require that separate Property Custody Reports are issued for all firearms, currency, controlled substances, and all other items taken into custody. The PCR, along with the items of property, is turned in to the property clerk who then assigns them a location in the property room. While the property room is usually located at police headquarters, some departments may utilize off-site storage facilities for larger items such as cars and boats.

Accreditations standards require that detailed written procedures be maintained to provide guidance to the property clerks regarding the storage, release, and disposition of physical property. While individual procedures will vary, all handguns, cash, controlled substances and items of large value should be stored in locked cabinets within a locked property storage vault or room. Access to both the property room and locked cabinets should be restricted to the property clerks and a limited number of senior-level police officers.

Property held by a department may be released from the property room for a variety of reasons, illustrated in Exhibit 1. Controlled substances and guns might be released for crime lab analysis. Items may be released temporarily to lawyers involved in a criminal proceeding and subsequently released for use as evidence at trial. In cases involving multiple agencies such as the IRS or FBI, items may be transferred to these agencies for use in conducting and furthering their investigation.

Various alternatives exist for the final disposition of property in police custody. If the property is no longer necessary in a criminal prosecution, it may be returned to the rightful owner. Certain types of physical property may be authorized for destruction or sold at public auction. Proceeds from an auction, net of any associated costs, are distributed in a manner prescribed by the organization having jurisdiction over the police agency and applicable state laws. Property seized under the Federal Asset Forfeiture Programs is forwarded to the Department of Justice.

As noted previously, in order to properly document the chain of custody, all movement in and out of the property room needs to be recorded on the Property Custody Report and signed for by the recipient of the property.

\section{Planning the Audit of a Property Room}

Some basic planning procedures should be completed before beginning an audit of the property room. Specific procedures will vary depending on the nature and complexity of the audit but the following identifies some of the minimum planning requirements:

- Talk with law enforcement officials from the police unit to gain an understanding of the types and location of physical property.

- $\quad$ Tour the facilities and talk with personnel involved in maintaining the property room(s). 
- $\quad$ Review prior audit reports for this and other comparable police departments.

- $\quad$ Prepare a written engagement letter. Document the scope of the work to be performed, the police department's objective, the kind of report that will be forthcoming at the end of the engagement.

- $\quad$ Review applicable laws and accreditation standards for the recording, safeguarding, storage, and control of physical property.

- $\quad$ Arrange visits to other police department property rooms in the area.

- $\quad$ Visit a crime lab to review the process for handling evidence and confiscated property.

- Determine the expertise and staffing requirements of the job. Experience working with the criminal justice system and experience in physical inventory audits is a definite advantage. For CPA's performing the audit, it is important that state and governmental CPE requirements are met.

- $\quad$ Draft the work programs and continuously monitor and update as the audit progresses.

\section{Performing the Audit of a Property Room}

Once the auditor understands and documents the flow of physical property in and out of the property room, testing of control procedures and an audit of the physical property can begin. It is important to make sure the testing is multidirectional. A sample of items physically located in the property room should be selected and traced back to the corresponding Property Custody Report and, if applicable, associated crime report. More importantly, a sample of crime reports and Property Custody Reports should be selected, and physical property identified on these documents should be physically observed in the property room, or verification received that the property has been disposed of in a proper manner.

For testing purposes, the auditor should separate the property into two categories, one category for high risk or high value items such as narcotics, firearms, jewelry and money, and another for general items such as clothing and evidence held in petit larceny cases. A larger percentage of high risk/high value items should be sampled with individual items selected using either statistical sampling methods or judgmental sampling. Once testing of the items begins, it is important to continually update management on the status of the audit and on weaknesses in control procedures that will be addressed in the final report. Near the completion of the audit, the auditor should obtain a management representation letter and review a draft of the report with property room personnel to verify information is accurate, recommendations are appropriate and proposed changes are within legal guidelines.

\section{Recommendations to Management}

Recommendations to improve both the efficiency and effectiveness of property room control procedures will vary depending on the auditor's findings. However, recommendations will generally address the following areas:

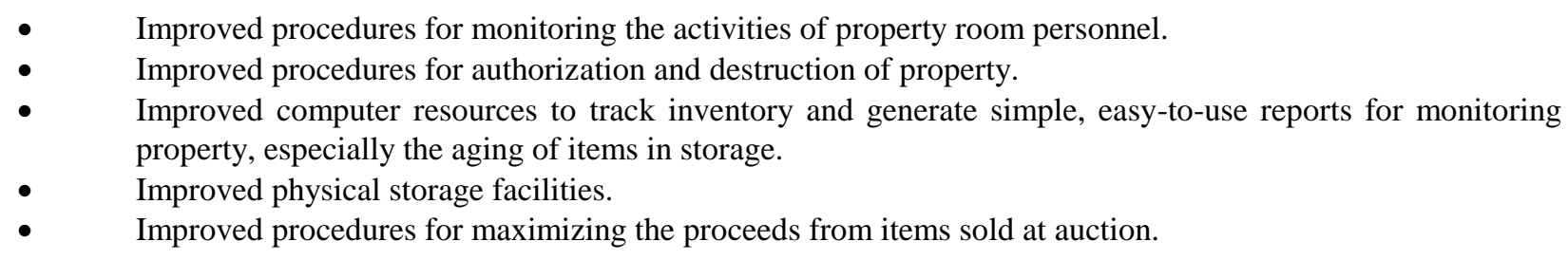

\section{Summary}

Like other organizations, police agencies need adequate controls over assets in their possession to ensure the agencies' objectives are accomplished. Federal Asset Forfeiture Programs have increased the amount of money available to local law enforcement agencies to fight the war on crime. However, with this increase comes the need for increased controls to ensure the money is used for its intended purpose. Additionally, police agencies need to ensure that property in their possession is properly recorded, safeguarded and disposed of in accordance with applicable laws. Ineffective procedures can result in mistrials or acquittals in criminal trials or temptations for police to use 
the property in an improper manner.

With over 15,000 local law enforcement agencies in the U.S., opportunities exist for auditors to assist police agencies design effective and efficient procedures for control of cash and property. Auditor involvement can improve police performance in these areas and help maintain public confidence in the police department's ability to serve and protect the public interest.

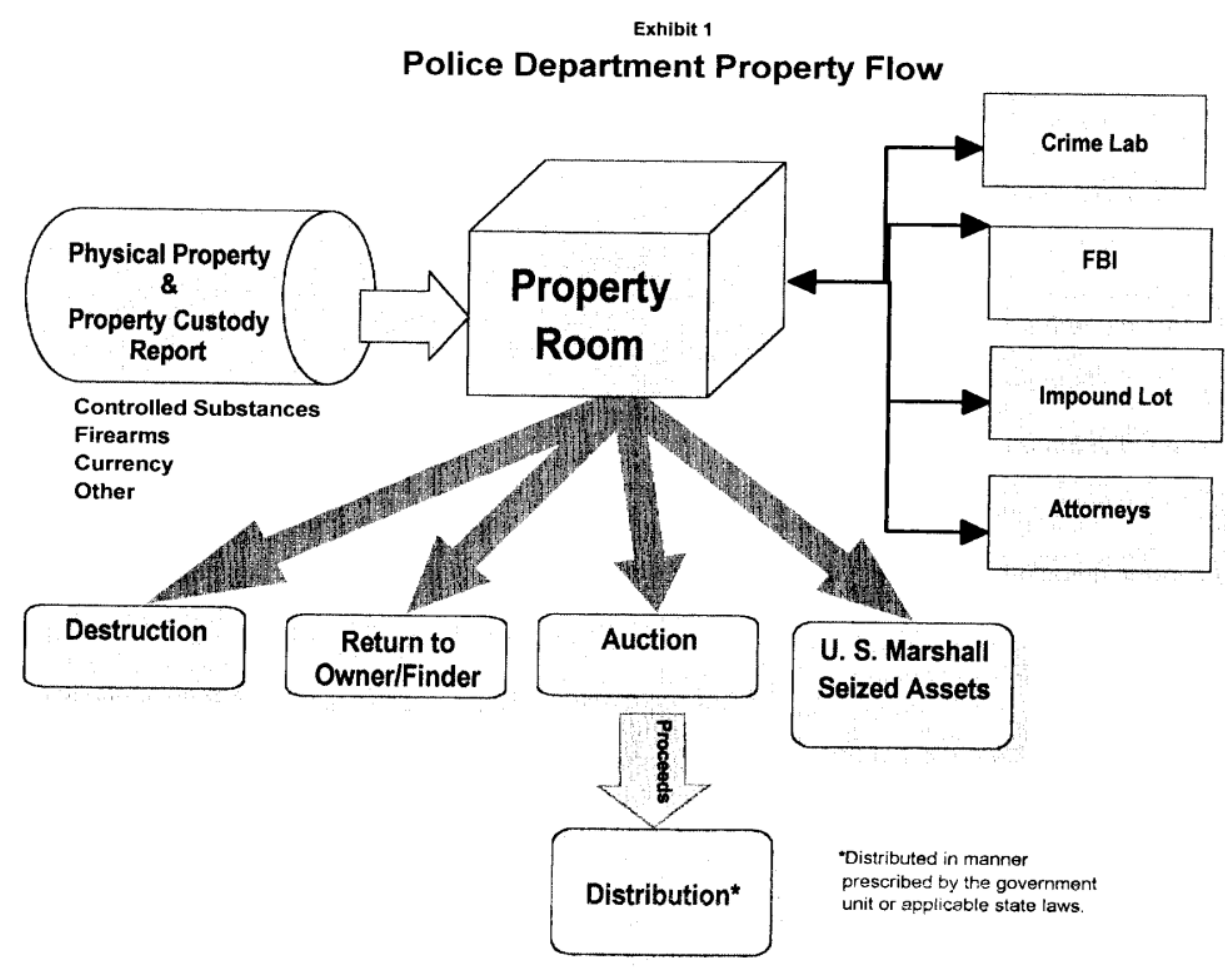

\section{References}

1. $\quad$ Adams, Jim. 1997. "Mishandled Drug Money”. Minneapolis Star Tribune. 3 January.

2. Dillon, Karen. 2000. "Widespread police woes reported around U.S." The Kansas City Star. 23 August.

3. Grow, Doug. 1997. "Is property room fiasco really over?" Minneapolis Star Tribune. 19 January.

4. Mills, Steven. 1992. Ex-Chief Sentenced to 4 Years in Prison. Rochester Democrat \& Chronicle. 6 May.

5. Mills, Steven. 1992. Phony Books hid Uhrlacher's Scheme. Rochester Democrat \& Chronicle. 1 February.

6. New York Times. 1994. "Excerpts of What the Mollen Commission Found". 7 July.

7. New York Times. 1994. "9 New Orleans Police Officers are indicted in U.S. Drug Case". 8 December.

8. $\quad$ Sullivan, John. 1996. "Newark Police Head Charged in Theft". New York Times. 21 June.

9. United States Department of Commerce. 1999. Statistical Abstract of the United States.

10. United States Department of Justice, Federal Bureau of Investigation. 1996. Crime in the United States 1996 - Uniform Crime Reports.

11. United States Department of Justice. 1994. A Guide to Equitable Sharing of Federally Forfeited Property for States and Local Law Enforcement Agencies.

12. United States Department of Justice. 1990. Accounting for Federal Asset Forfeiture Funds. 
Notes 